PARINI, Pedro; DE ABREU, Dã Filipe Santos. As estratégias retóricas na argumentação jurídica: estudo de caso da ação cautelar no 4039/DF. Revista Eletrônica Direito e Política, Programa de PósGraduação Stricto Sensu em Ciência Jurídica da UNIVALI, Itajaí, v.14, n.1, $1^{\circ}$ quadrimestre de 2019. Disponível em: www.univali.br/direitoepolitica - ISSN 1980-7791

\title{
AS ESTRATÉGIAS RETÓRICAS NA ARGUMENTAÇÃO JURÍDICA: ESTUDO DE CASO DA AÇÃO CAUTELAR No 4039/DF
}

\author{
THE RETHORICAL STRATEGIES IN LEGAL ARGUMENTATION: A CASE STUDY ON \\ "AÇÃO CAUTELAR" NO 4039/DF
}

Pedro Parini ${ }^{1}$

Dã Filipe Santos de Abreu²

\section{RESUMO}

O presente artigo tem como objetivo descobrir as estratégias argumentativas usadas na decisão judicial, proferida na Ação Cautelar no 4039/DF, que determinou a prisão preventiva de um senador da República, algo até então inédito e que contraria a interpretação literal do artigo $53, \S 2^{\circ}$, da Constituição Federal. Como metodologia de análise, aplicou-se a retórica analítica, na forma como pensada inicialmente por Ottmar Ballweg e desenvolvida posteriormente por João Maurício Adeodato e Pedro Parini. Este trabalho começa apresentando os três níveis do método retórico, seguindo-se breve exposição de algumas estratégias da argumentação e após é feito o estudo do caso. Na conclusão, são tecidos comentários sobre os motivos que levaram o julgador a escolher aqueles argumentos e é discutida a utilidade de uma análise retórica no direito.

PALAVRAS-CHAVE: retórica jurídica; argumentação jurídica; estratégias argumentativas; prerrogativas parlamentares; imunidade processual parlamentar.

\begin{abstract}
The article aims to discover the argumentative strategies applied in the judicial decision, taken in the "Ação Cautelar" no 4039/DF, that determined the preventive arrest of a Republic senator, something unprecedented and opposite to the literal meaning of the article 53, 2nd paragraph, of the Brazilian Constitution. As methodology of analysis, we use the analytical rhetorical approach, as initially theorized by Ottmar Ballweg and later developed by João Maurício Adeodato and Pedro Parini. This paper starts presenting the three levels

\footnotetext{
${ }^{1}$ Doutor e mestre pela Universidade Federal de Pernambuco (UFPE). Pós-doutorado pela Università di Bologna com financiamento da CAPES. Professor adjunto do Departamento de Teoria Geral do Direito e Direito Privado da Faculdade de Direito do Recife e docente permanente do Programa de Pós-Graduação em Direito da Universidade Federal de Pernambuco (UFPE). Coordenador do grupo de pesquisa "Direito e Persuasão". E-mail: pparini@gmail.com

2 Mestrando em direito pela Universidade Federal de Pernambuco (UFPE). Servidor da Assembleia Legislativa do Estado de Pernambuco (ALEPE). Advogado. Membro do grupo de pesquisa "Direito e Persuasão". E-mail: dfibiop@gmail.com
} 
PARINI, Pedro; DE ABREU, Dã Filipe Santos. As estratégias retóricas na argumentação jurídica: estudo de caso da ação cautelar no 4039/DF. Revista Eletrônica Direito e Política, Programa de PósGraduação Stricto Sensu em Ciência Jurídica da UNIVALI, Itajaí, v.14, n.1, 10 quadrimestre de 2019. Disponível em: www.univali.br/direitoepolitica - ISSN 1980-7791

of the rhetorical methodology, then follows a brief exposition of some argumentative strategies and after that we work on the case. In the conclusion we comment on the reasons who lead the judge to choose those arguments and also discuss about the utility of a rhetorical analysis in law.

KEYWORDS: juridical rhetoric; juridical argumentation; argumentative strategies; parliamentary privileges; freedom from arrest.

\section{INTRODUÇÃo}

Ao estudar o direito positivo e ao elaborar teorias sobre o seu funcionamento, devemos observar dois elementos fundamentais: seu caráter argumentativo e decisional ${ }^{3}$. Devemos considerar também que a retórica "tradicional" do "saber" jurídico consiste em fazer passar por saber o que, no fundo, é querer - sabido ou alienado ${ }^{4}$.

Do ponto de vista metodológico, para o desenvolvimento deste trabalho, empregaremos o esquema da retórica analítica, inicialmente da forma como a pensou Ottmar Ballweg ${ }^{5}$, e posteriormente desenvolvida no trabalho de outros autores, cada qual em um sentido próprio como Adeodato, Sobota e Parini.

O objetivo do estudo é aplicar a metodologia da retórica analítica ao caso concreto escolhido, a fim de apresentar e explicitar as estratégias da retórica prática empregadas pelo então Ministro do Supremo Tribunal Federal Teori Zavascki, na Ação Cautelar no 4039/DF, para fundamentar a decisão que determinou a prisão preventiva de um Senador da República, indo de encontro a uma suposta interpretação literal do art. 53, § 20, da Constituição Federal.

\footnotetext{
3 SCHROTH, Ulrich; SCHNEIDER, Jochen. Perspectivas da aplicação da norma jurídica: determinação, argumentação e decisão. In: KAUFMANN; HASSEMER (org.) Introdução à filosofia do direito e teoria do direito contemporâneas. Lisboa: Fundação Calouste Gulbenkian, 2002, p. 523

${ }^{4}$ CASTRO JR., Torquato. A bola do jogo: uma metáfora performativa para o desafio da pragmática da norma jurídica. In: Adeodato, J. M.; Bittar, E. C. B. (Org.). Filosofia e teoria geral do direito: homenagem a Tercio Sampaio Ferraz Júnior. São Paulo: Quartier Latin, 2011. p. 1084

${ }^{5}$ BALLWEG, Ottmar. Retórica analítica e direito. Tradução de J. M. Adeodato. Revista Brasileira de Filosofia, v. XXXIX, Fasc. 163, jul-ago-set, 1991, p. 179.
} 
PARINI, Pedro; DE ABREU, Dã Filipe Santos. As estratégias retóricas na argumentação jurídica: estudo de caso da ação cautelar no 4039/DF. Revista Eletrônica Direito e Política, Programa de PósGraduação Stricto Sensu em Ciência Jurídica da UNIVALI, Itajaí, v.14, n.1, 10 quadrimestre de 2019. Disponível em: www.univali.br/direitoepolitica - ISSN 1980-7791

Em razão do corte epistemológico aqui adotado, as estratégias retóricas objeto de nossa análise foram limitadas às estruturas dos argumentos, conforme catalogadas por Chaïm Perelman, às quais dedicamos parte deste trabalho.

\section{A METOdOLOGIA RETÓRICA APLICADA AO DIREITO}

Para Ballweg, a atividade judicial consiste em resolver problemas, os quais surgem por meio da linguagem enquanto objeto (a retórica em seu aspecto material) e só podem ser resolvidos com ferramentas fornecidas pela própria linguagem enquanto conjunto de estratégias da retórica prática ${ }^{6}$. Para ele, há cinco constrangimentos essenciais a que a atividade judicial é submetida: decidir, interpretar, justificar, estabelecer normas e agir com profissionalismo ${ }^{7}$. 0 direito só conseguiria satisfazer essas exigências quando se expressasse por meio de uma linguagem retórica que veicula opiniões (doxa), para isso lançando mão de ferramentas linguísticas como conceitualismos, ontologizações e reificação de conceitos $^{8}$.

Em sua teoria, Ballweg, com base nas ideias que Nietzsche desenvolve a partir de Aristóteles ${ }^{9}$, apresenta três diferentes níveis para a retórica: o nível material, o prático e o analítico.

No âmbito da retórica material está a própria comunicação humana enquanto conjunto de fenômenos de variadas formas e diferentes graus de importância na constituição daquilo que se chama ordinariamente de realidade.. A retórica material é o meio por que se constitui a comunicação ${ }^{10}$ e a própria realidade

\footnotetext{
6 BALLWEG, Ottmar. Analytical rhetoric, semiotic and law. In: KEVELSON, Roberta. Law and semiotics. v. 1. New York: Plenum Press, 1987, p. 26.

7 BALLWEG, Ottmar. Analytical rhetoric, semiotic and law. In: KEVELSON, Roberta. Law and semiotics. v. 1. New York: Plenum Press, 1987, p. 27.

8 BALLWEG, Ottmar. Analytical rhetoric, semiotic and law. In: KEVELSON, Roberta. Law and semiotics. v. 1. New York: Plenum Press, 1987, p. 27.

9 PARINI, Pedro. A análise retórica na teoria do direito. Cadernos do Programa de PósGraduação em Direito/UFRGS. Vol. 12, no 1, 2017, p. 122.
}

10 ADEODATO, João Maurício. A retórica constitucional. Sobre tolerância, direitos humanos e 
PARINI, Pedro; DE ABREU, Dã Filipe Santos. As estratégias retóricas na argumentação jurídica: estudo de caso da ação cautelar no 4039/DF. Revista Eletrônica Direito e Política, Programa de PósGraduação Stricto Sensu em Ciência Jurídica da UNIVALI, Itajaí, v.14, n.1, 10 quadrimestre de 2019. Disponível em: www.univali.br/direitoepolitica - ISSN 1980-7791

linguística que existe para nós enquanto seres que se comunicam inexoravelmente e que se encontram em uma posição de imanência em relação aos sinais que empregamos ao tentar nos expressar, compreender e ser compreendidos. No direito, a retórica material revela-se através de textos legais e decisões judiciais, os quais são os meios encontrados pela sociedade para prescrever normas de conduta a serem observadas por destinatários determinados (decisão) ou indeterminados (legislação lato sensu) ${ }^{11}$ e cumprir sua função primordial, que é a resolução de conflitos, mais no sentido de neutralização do dissenso do que de solução efetiva de problemas. Diante da impossibilidade de se estabelecerem consensos em sociedades altamente complexas como as contemporâneas, o papel retórico da dogmática jurídica se limita a inibir a proliferação de desacordos capazes de provocar inúmeros tipos de conflitos.

A retórica prática ou estratégica é uma forma de reflexão sobre a retórica material. Ela observa como funciona a retórica material e verifica que fórmulas dão certo, construindo uma pragmática finalística e normativa da comunicação ${ }^{12}$. É neste nível retórico que estão situados os métodos de interpretação e as estratégias prescritas pela argumentação jurídic ${ }^{13}$, enquanto as formas "certas" de determinar o sentido e o alcance dos dogmas jurídicos (retórica material). É a "metodologia" da "ciência" do direito ${ }^{14}$, ou mais propriamente da dogmática jurídica, com a qual o julgador se desvencilha dos constrangimentos a que está submetido.

Por fim, a retórica analítica é o nível retórico último, o qual busca observar os usos das retóricas materiais por meio das estratégias das retóricas práticas, sem

outros fundamentos éticos do direito positivo. São Paulo: Saraiva, 2010, p. 68.

11 ADEODATO, João Maurício. Retórica analítica da dogmática jurídica existencial e estratégica. Revista duc in altum. Caderno de Direito, vol. 4, no 5, jan-jun. 2012, p. 195-196.

12 ADEODATO, João Maurício. A retórica constitucional. p. 73.

13 BALLWEG, Ottmar. Retórica analítica e direito. Tradução de J. M. Adeodato. Revista Brasileira de Filosofia, v. XXXIX, Fasc. 163, jul-ago-set, 1991, p. 178.

14 ADEODATO, João Maurício. Retórica analítica da dogmática jurídica existencial e estratégica. Revista duc in altum. Caderno de Direito, vol. 4, no 5, jan-jun. 2012, p. 197-198. 
PARINI, Pedro; DE ABREU, Dã Filipe Santos. As estratégias retóricas na argumentação jurídica: estudo de caso da ação cautelar no 4039/DF. Revista Eletrônica Direito e Política, Programa de PósGraduação Stricto Sensu em Ciência Jurídica da UNIVALI, Itajaí, v.14, n.1, 10 quadrimestre de 2019. Disponível em: www.univali.br/direitoepolitica - ISSN 1980-7791

emitir juízos axiológicos ${ }^{15}$. Nesse sentido, a retórica analítica é uma metalinguagem tanto em relação à retórica material quanto em relação à retórica prática.

A retórica como um método (no sentido "débil") do direito - isto é, como indicação de que os caminhos para a elaboração dos raciocínios jurídicos são retóricos ${ }^{16}$ - não está preocupada em definir categorias ou julgar se elas foram aplicadas "corretamente". O alvo é apontar onde estão e como funcionam as estratégias persuasivas que a dogmática jurídica emprega para neutralizar o dissenso e camuflar eficientemente seu aspecto "necessariamente arbitrário"17. Em Ballweg, o desenvolvimento da retórica analítica parte de um ceticismo que não deixa espaço para critérios normativos do que seria boa ou má decisão. Deste modo, a teoria rejeita critérios metafísicos de avaliação como, por exemplo, o "auditório universal" de Perelman ou o "consenso" de Blumenberg ${ }^{18}$.

Dentro da retórica analítica, Ballweg ${ }^{19}$ destaca as relações entre sujeitos (ou utentes da língua), signos ou sinais (linguísticos) e objetos (eventos não linguísticos do mundo físico e espiritual) sob três perspectivas, a partir da importância que cada um dos elementos adquire sobre os demais no âmbito específico de cada parte da análise:

A fronética parte do sujeito $(S)$ para observar as relações entre Sujeitos $(S \rightarrow S)$, entre Sujeito e Objeto $(S \rightarrow O$ ) e entre Sujeito e Sinal ( $\rightarrow Z$ ), chamadas respectivamente de agôntica, ergôntica e pitanêutica.

Na agôntica, a análise recai sobre o inter-relacionamento entre os sujeitos, isto é, definição de papeis, reconhecimento, status jurídico, enfim, "sobre as posições

15 ADEODATO, João Maurício. A retórica constitucional. p. 74.

16 PARINI, Pedro. Retórica como método no direito: o entimema e o paradigma como bases de uma retórica judicial analítica. João Pessoa: Editora da UFPB, 2015, p. 18.

17 ADEODATO, João Maurício. Ética \& retórica: para uma teoria da dogmática jurídica. São Paulo: Saraiva, 2002, p. 34.

18 SOBOTA, Katharina. System and flexibility in law. Argumentation. August 1991, Volume 5, Issue 3, p. 276-277.

19 BALLWEG, Ottmar. Retórica analítica e direito. Tradução de J. M. Adeodato. Revista Brasileira de Filosofia, v. XXXIX, Fasc. 163, jul-ago-set, 1991, p. 180-182. 
PARINI, Pedro; DE ABREU, Dã Filipe Santos. As estratégias retóricas na argumentação jurídica: estudo de caso da ação cautelar no 4039/DF. Revista Eletrônica Direito e Política, Programa de PósGraduação Stricto Sensu em Ciência Jurídica da UNIVALI, Itajaí, v.14, n.1, 10 quadrimestre de 2019. Disponível em: www.univali.br/direitoepolitica - ISSN 1980-7791

que ocupam os sujeitos dentro desses vários mundos a que chamamos real, ideal, imaginário etc." 20 . Cada um desses sujeitos ocupa uma posição diferenciada no discurso em relação a seus papeis institucionais. Ademais, interessam também as outras dimensões sociais que se projetam no discurso jurídico.

A análise ergôntica, por seu turno, é aplicada sobre tudo aquilo que é considerado objeto em relação a um sujeito; aqui, o objeto será compreendido a partir do sujeito, tendo este a primazia sobre aquele. É neste nível de análise que os sujeitos determinam o que é o "mundo real" do direito, quais são as "coisas" do direito, aquilo que pode ser reificado como algo material ou substancialmente válido ${ }^{21}$. Neste estrato, é desmascarada a "despersonificação do direito", artifício por meio do qual a dogmática jurídica desvincula os conceitos de seus criadores e idealizadores mascarando suas ideologias e idiossincrasias.

Por fim, a pitanêutica serve ao exame da forma pela qual os sujeitos manipulam os sinais que devem empregar nos vários domínios específicos de um sistema linguístico. Aqui, os juristas determinam quais seriam as "palavras certas" em cada uma das diversas situações enfrentadas pelo direito; deste modo, por exemplo, "prescrição" e "decadência" têm um significado e um uso estabelecido no direito civil, mas no direito tributário seu uso é diferente ${ }^{22}$. Estes usos são o fruto de manipulação e determinação dos sinais pelos sujeitos.

A holotática (ou holística) parte do Objeto (O) para analisar as relações entre Objetos $(\mathrm{O} \rightarrow \mathrm{O})$, entre Objeto e Sinal $(\mathrm{O} \rightarrow \mathrm{Z}$ ) e entre Objeto e Sujeito $(\mathrm{O} \rightarrow \mathrm{S})$, nomeadas respectivamente de ontotática, axiotática e teleotática.

\footnotetext{
20 PARINI, Pedro. A análise retórica na teoria do direito. Cadernos do Programa de PósGraduação em Direito/UFRGS. Vol. 12, no 1, 2017, p.126.

21 PARINI, Pedro. A análise retórica na teoria do direito. Cadernos do Programa de PósGraduação em Direito/UFRGS. Vol. 12, no 1, 2017, p. 127-128.

22 PARINI, Pedro. A análise retórica na teoria do direito. Cadernos do Programa de PósGraduação em Direito/UFRGS. Vol. 12, nº 1, 2017, p 127-128.
} 
PARINI, Pedro; DE ABREU, Dã Filipe Santos. As estratégias retóricas na argumentação jurídica: estudo de caso da ação cautelar no 4039/DF. Revista Eletrônica Direito e Política, Programa de PósGraduação Stricto Sensu em Ciência Jurídica da UNIVALI, Itajaí, v.14, n.1, 10 quadrimestre de 2019. Disponível em: www.univali.br/direitoepolitica - ISSN 1980-7791

A ontotática estuda a "ontologização" dos significados e sua ação sobre os objetos, ou seja, quando um objeto adquire status de realidade independentemente do contexto e dos sujeitos que o circundam e passa a determinar a realidade que, por seu turno, passa a constituir outros objetos ${ }^{23}$.

Na relação axiotática, o objeto passa a dominar o sinal, e o nome deixa de ser uma atribuição arbitrária e passa a depender do "ser" da coisa, como se apenas expressasse este $\operatorname{ser}^{24}$.

$\mathrm{Na}$ relação teleotática o indivíduo perde sua subjetividade e individualidade, tornando-se uma figura objetiva - como "réu", "contratante", "apelante" etc. ${ }^{25}$. Neste aspecto da holotática, o objeto - seja ele um conceito ou uma posição na relação processual - define os sujeitos a que se dirige.

A semiótica, por seu turno, parte do Sinal (Z) para analisar as relações entre Sinais $(Z \rightarrow Z)$, entre Sinal e Objeto $(Z \rightarrow O)$ e entre Sinal e Sujeito $(Z \rightarrow S)$, conhecidas respectivamente como sintaxe, semântica e pragmática.

No plano da sintaxe estão os problemas relativos à lógica jurídica, às lacunas normativas e às antinomias, por exemplo. Para que a sintaxe se constitua uma preocupação pertinente para a retórica jurídica, é preciso pressupor a univocidade da língua ${ }^{26}$.

Na semântica, o interesse é definir qual objeto é referido por um determinado sinal. É onde está situada a discussão sobre o alcance e limite de um conceito ${ }^{27}$.

23 PARINI, Pedro. A análise retórica na teoria do direito. Cadernos do Programa de PósGraduação em Direito/UFRGS. Vol. 12, no 1, 2017, p. 130.

24 PARINI, Pedro. A análise retórica na teoria do direito. Cadernos do Programa de PósGraduação em Direito/UFRGS. Vol. 12, n 1, 2017, p. 130.

25 PARINI, Pedro. A análise retórica na teoria do direito. Cadernos do Programa de PósGraduação em Direito/UFRGS. Vol. 12, no 1, 2017, p. 130-131.

26 PARINI, Pedro. A análise retórica na teoria do direito. Cadernos do Programa de PósGraduação em Direito/UFRGS. Vol. 12, no 1, 2017, p. 131.

27 PARINI, Pedro. A análise retórica na teoria do direito. Cadernos do Programa de PósGraduação em Direito/UFRGS. Vol. 12, no 1, 2017, p. 131. 
PARINI, Pedro; DE ABREU, Dã Filipe Santos. As estratégias retóricas na argumentação jurídica: estudo de caso da ação cautelar no 4039/DF. Revista Eletrônica Direito e Política, Programa de PósGraduação Stricto Sensu em Ciência Jurídica da UNIVALI, Itajaí, v.14, n.1, 10 quadrimestre de 2019. Disponível em: www.univali.br/direitoepolitica - ISSN 1980-7791

Por fim, a pragmática estuda as questões relativas ao uso da língua pelos sujeitos; contudo, ao contrário da pitanêutica, aqui o sinal predomina sobre o sujeito e prepondera no momento do $u^{28}{ }^{28}$.

Apresentados os três âmbitos da retórica analítica, pretendemos restringir nossa análise à fronética e à holotática, primeiro porque a semiótica é velha conhecida da teoria do direito, não faltando autores - brasileiros e estrangeiros - que estudam o tema. O segundo motivo, decorrente do primeiro, é verificar se as dimensões acrescentadas por Ballweg (fronética e holística) auxiliam o processo de observação das retóricas estratégica e material, ou se apenas a semiótica seria suficiente para uma análise retórica.

\section{A RETÓRICA PRÁtICA COMO CONJUNTO DE TÉCNICAS OU ESTRATÉGIAS DE PERSUASÃo}

\subsection{As técnicas argumentativas e sua classificação de acordo com a Nova Retórica}

Levando em consideração os três diferentes níveis da retórica, podemos destacar algumas técnicas argumentativas como estratégias típicas da retórica prática. A argumentação dogmática, destinada à obtenção de resultados práticos e compromissada com o processo decisório, é orientada, explícita ou implicitamente, por uma série de estratégias de expressão oral e textual.

No entanto, para um estudo que toma a retórica analítica metodologia, a prescrição de métodos "certos" para se chegar à interpretação "correta" não passa de mais uma estratégia de convencimento, a qual lança mão de uma linguagem metafórica para tentar aparentar descrever a realidade "ela mesma"29.

\footnotetext{
28 PARINI, Pedro. A análise retórica na teoria do direito. Cadernos do Programa de PósGraduação em Direito/UFRGS. Vol. 12, no 1, 2017, p. 131-132.

29 PARINI, Pedro. A retórica da metáfora dos modelos na teoria do direito. Seqüência (Florianópolis), n. 67, dez. 2013, p. 84.
} 
PARINI, Pedro; DE ABREU, Dã Filipe Santos. As estratégias retóricas na argumentação jurídica: estudo de caso da ação cautelar no 4039/DF. Revista Eletrônica Direito e Política, Programa de PósGraduação Stricto Sensu em Ciência Jurídica da UNIVALI, Itajaí, v.14, n.1, 10 quadrimestre de 2019. Disponível em: www.univali.br/direitoepolitica - ISSN 1980-7791

Conforme explica Perelman ${ }^{30}$, seu estudo sobre as técnicas argumentativas trata de uma análise da estrutura dos argumentos que frequentemente constituem os discursos.

Cumpre, contudo, atentar para o alerta do autor: os argumentos de um discurso se interpenetram e, na maioria dos casos, um mesmo argumento pode ser enquadrado em mais de uma categoria, a depender daquele que faz a análise ${ }^{31}$. Portanto, a leitura a que nos propomos aqui não pode ser, em hipótese alguma, considerada definitiva, estanque ou inquestionável; o maior objetivo é trazer a lume como se desenrolou, em caso específico, o discurso judicial que pretende persuadir seu auditório de que a decisão tomada é fruto de um raciocínio neutro, objetivo, correto e legítimo. Perelman ${ }^{32}$ divide os argumentos em dois grandes grupos: argumentos de ligação e argumentos de dissociação, embora advirta que ambos são complementares e inter-relacionados.

Os argumentos de ligação são os que aproximam elementos distintos e permitem estabelecer entre eles uma solidariedade que visa estruturá-los ou valorizá-los (positiva ou negativamente) um pelo outro. Nesta categoria se enquadram os argumentos: quase-lógicos; baseados na estrutura do real; e fundantes da estrutura do real.

Os argumentos de dissociação se caracterizam por remanejar os conceitos e remodelá-los, a fim de distinguir situações que são vistas como próximas.

Nossa análise ficará restrita a dois subgrupos: o dos "argumentos quase-lógicos" e o dos "argumentos baseados na estrutura do real", ambos pertencentes ao grupo dos "argumentos de ligação". A seguir, faremos um resumo de cada um desses grupos, e apresentaremos seus componentes mais relevantes para 0 estudo de caso em tela.

30 PERELMAN, Chaïm; OLBRECHTS-TYTECA, Lucie. Tratado da Argumentação: a Nova Retórica. São Paulo: Martins Fontes, 2005, p. 212.

31 PERELMAN, Chaïm; OLBRECHTS-TYTECA, Lucie. Tratado da Argumentação: a Nova Retórica. p. 217.

32 PERELMAN, Chaïm; OLBRECHTS-TYTECA, Lucie. Tratado da Argumentação: a Nova Retórica. p. 215-217. 
PARINI, Pedro; DE ABREU, Dã Filipe Santos. As estratégias retóricas na argumentação jurídica: estudo de caso da ação cautelar no 4039/DF. Revista Eletrônica Direito e Política, Programa de PósGraduação Stricto Sensu em Ciência Jurídica da UNIVALI, Itajaí, v.14, n.1, 10 quadrimestre de 2019. Disponível em: www.univali.br/direitoepolitica - ISSN 1980-7791

\subsection{Argumentos quase-lógicos}

\subsubsection{Contradição e incompatibilidade}

Perelman explica que os argumentos quase-lógicos se baseiam na indicação ou elaboração de uma estrutura lógica e na tentativa de encaixar a argumentação numa estrutura desse tipo; ou de apontar que a argumentação do adversário não se enquadra nesse esquema. Sua força consiste em se comparar o argumento a uma estrutura lógica, portanto a priori, demonstrável e inegável ${ }^{33}$. Contudo, ao ouvinte (ou leitor) mais atento não escapa que somente uma redução de cunho não-formal pode enquadrar os dados na estrutura formal, emprestando-Ihes aparência demonstrativa, ou seja, uma suposta formalização. Passamos, neste tópico, a apresentar alguns dos argumentos quase-lógicos catalogados por Perelman:

$\mathrm{Na}$ linguagem formal, a contradição acontece quando o sujeito afirma e nega algo simultaneamente $(P \wedge \sim P)$. Na linguagem comum, $O$ sentido de uma proposição em geral não é unívoco, o que acarreta tentativas de conciliar duas afirmações que aparentemente se chocam; deste modo, Perelman alerta que se deve falar em "incompatibilidade" na linguagem natural.

Diante de uma incompatibilidade, o orador pode abandonar uma de suas afirmações; pode tentar conciliar as duas afirmações; ou pode dizer que elas são sucessivas no tempo. Caso a incompatibilidade seja mantida e o orador precise abandonar uma (ou mais) de suas asserções, o autor descreve três tipos de atitudes possíveis: 1. Lógica; 2. Prática; 3. Diplomática.

A atitude lógica é aquela em que o orador procura destrinchar suas afirmações, a fim de indicar os casos em que elas são incompatíveis, quais situações em que não o são, enfim, minudenciar todas as possibilidades e sentidos que lhe vêm à tona.

33 PERELMAN, Chaïm; OLBRECHTS-TYTECA, Lucie. Tratado da Argumentação: a Nova Retórica. p. $219-220$. 
PARINI, Pedro; DE ABREU, Dã Filipe Santos. As estratégias retóricas na argumentação jurídica: estudo de caso da ação cautelar no 4039/DF. Revista Eletrônica Direito e Política, Programa de PósGraduação Stricto Sensu em Ciência Jurídica da UNIVALI, Itajaí, v.14, n.1, 10 quadrimestre de 2019. Disponível em: www.univali.br/direitoepolitica - ISSN 1980-7791

$\mathrm{Na}$ atitude prática, o orador não se aprofunda nas consequências de suas asserções; para ele, é interessante deixar aberta a possibilidade futura de mudar a opinião, ou não se comprometer em demasiado com um argumento; portanto, ele se preocupa em resolver apenas a incompatibilidade presente.

Na atitude diplomática, o orador foge do problema, procurando uma solução que Ihe evite enfrentar a incompatibilidade e ter de escolher dentre as asserções mesmo que gerando novas incompatibilidades ou maximizando problemas futuros.

\subsubsection{A regra de justiça}

A regra de justiça determina que, a situações idênticas, sejam aplicadas as mesmas regras e princípios. É ela quem fundamenta a aplicação de precedentes ( $\mathrm{e}$, até mesmo, a existência da lei como padrão universal, impessoal e genérico de condutas). Requer, deste modo, a categorização dos seres e eventos e seu enquadramento em alguma das categorias estabelecidas. Contudo, a adaptação desta regra lógica ao plano da realidade necessita que se demonstre a identidade entre as situações apreciadas, e tal demonstração é problemática porque nunca, no mundo fático, dois eventos serão realmente iguais, apenas semelhantes ${ }^{34}$. Para o adversário, a rejeição da regra de justiça passa por expor que os eventos não possuem identidade entre si, acarretando a inaplicabilidade da regra entre eles. Por essa razão, uma das principais estratégias dogmáticas é a da dissociação de noções como, por exemplo, para deixar de aplicar um precedente a um caso, alegando a sua defeasibility.

\subsubsection{Argumentos de reciprocidade}

Nesta modalidade de argumentos, também se requer a aplicação da mesma regra para duas situações consideradas correspondentes. No entanto, ao contrário da regra de justiça, a correspondência é indireta e exige a intervenção

34 PERELMAN, Chaïm; OLBRECHTS-TYTECA, Lucie. Tratado da Argumentação: a Nova Retórica. p. 248. 
PARINI, Pedro; DE ABREU, Dã Filipe Santos. As estratégias retóricas na argumentação jurídica: estudo de caso da ação cautelar no 4039/DF. Revista Eletrônica Direito e Política, Programa de PósGraduação Stricto Sensu em Ciência Jurídica da UNIVALI, Itajaí, v.14, n.1, 10 quadrimestre de 2019. Disponível em: www.univali.br/direitoepolitica - ISSN 1980-7791

da noção de simetria para sua aplicação ${ }^{35}$.

A introdução da simetria faz com que, em duas ou mais situações, seja(m) destacado(s) o(s) elo(s) que as aproximam e que parecem se impor em função da semelhança colocada em evidência.

A rejeição da reciprocidade consiste, por seu lado, em demonstrar as diferenças entre as situações propostas, argumentando pela assimetria que apresentam entre si.

\subsubsection{0 entimema}

Em razão de sua importância para o estudo da retórica, o entimema merece destaque dentre as estruturas argumentativas em geral. Como figura demonstrativa de raciocínio, surge a partir da distinção aristotélica entre raciocínios apodíticos, dialéticos e retóricos.

Os raciocínios apodíticos partem de premissas primordiais e verdadeiras. A partir delas retiram-se conclusões diferentes das iniciais ${ }^{36}$. A demonstração é a forma ideal desse tipo de raciocínio: tomam-se duas verdades e, a partir de sua combinação, chega-se a uma conclusão igualmente verdadeira. A dialética, por seu lado, é uma forma de pensar os problemas a partir de premissas plausíveis aquelas que parecem verossímeis a todos, ou à maioria, ou aos sábios e, dentre estes, a todos, ou à maioria, ou aos mais conhecidos e reputados ${ }^{37}$. Assim, o raciocínio dialético constrói soluções e argumentos a partir de premissas aceitáveis. A forma de expor esse tipo de raciocínio é o entimema, cuja cadeia de pensamento deve ser curta e pode partir de premissas pertinentes em alguns momentos $^{38}$. Assim, enquanto o silogismo partiria de premissas verdadeiras para

35 PERELMAN, Chaïm; OLBRECHTS-TYTECA, Lucie. Tratado da Argumentação: a Nova Retórica. p. 250.

${ }^{36}$ ARISTÓTELES. Tratados de Lógica (Órganon). Tradução de Miguel Candel Sanmartín. Madrid: Gredos, 1998. Tomo I. p. 90.

37 ARISTÓTELES. Tratados de Lógica (Órganon). p. 89-90.

38 ARISTÓTELES. Retórica. Tradução de Manuel Alexandre Júnior, Paulo Farmhouse Alberto e Abel do Nascimento Pena. Lisboa: Imprensa Nacional - Casa da Moeda, 2005. p. 214. 
PARINI, Pedro; DE ABREU, Dã Filipe Santos. As estratégias retóricas na argumentação jurídica: estudo de caso da ação cautelar no 4039/DF. Revista Eletrônica Direito e Política, Programa de PósGraduação Stricto Sensu em Ciência Jurídica da UNIVALI, Itajaí, v.14, n.1, $1^{0}$ quadrimestre de 2019. Disponível em: www.univali.br/direitoepolitica - ISSN 1980-7791

chegar a conclusões necessárias, o entimema parte de premissas plausíveis para chegar a conclusões aceitáveis.

A partir de Aristóteles e de suas definições, Katharina Sobota defende que o raciocínio judicial é entimemático - caracterizado pela ocultação de premissas e elaboração de raciocínios com premissas ocultas. O entimema seria o meio de apresentar a decisão legal que se vale de um aparente uso do silogismo, mas que esconde algumas premissas, a fim de evitar a repetição de normas autoevidentes ou, mesmo, porque seria embaraçoso e disfuncional citá-las e correr o risco de expor as incoerências e contradições da cadeia de raciocínio que conduziu à decisão judicial ${ }^{39}$.

\subsubsection{Inclusão da parte no todo}

Neste tipo de argumento, o orador procura demonstrar a relação que existe entre a parte e o todo que ela compõe; não há atribuição de qualidade particular à parte ou ao todo; a relação entre eles é quase de proporcionalidade ${ }^{40}$.

É aqui que temos os argumentos do gênero "o que vale para o todo vale para a parte". Por vezes, em razão da quantidade, o todo é tratado como mais importante que a parte, e o valor desta corresponderá a sua fração do todo.

\subsubsection{A divisão do todo em suas partes}

Nesta categoria, consideram-se as partes como constituintes do todo, sendo este a soma de suas partes.

O argumento de divisão é categorizado em dois tipos: o argumento gêneroespécie e o argumento por enumeração das partes ${ }^{41}$.

39 SOBOTA, Katharina. Don't mention the norm. International Journal for the semiotics of law IV/10. 1991, p. 49, 52 e 53.

40 PERELMAN, Chaïm; OLBRECHTS-TYTECA, Lucie. Tratado da Argumentação: a Nova Retórica. p. 262.

41 PERELMAN, Chaïm; OLBRECHTS-TYTECA, Lucie. Tratado da Argumentação: a Nova Retórica. p. 265-274. 
PARINI, Pedro; DE ABREU, Dã Filipe Santos. As estratégias retóricas na argumentação jurídica: estudo de caso da ação cautelar no 4039/DF. Revista Eletrônica Direito e Política, Programa de PósGraduação Stricto Sensu em Ciência Jurídica da UNIVALI, Itajaí, v.14, n.1, 10 quadrimestre de 2019. Disponível em: www.univali.br/direitoepolitica - ISSN 1980-7791

No gênero-espécie, o orador busca demonstrar que o evento faz parte de determinada espécie - e, por conseguinte, está enquadrado no gênero. Nesta estrutura argumentativa, não é preciso enumerar todas as espécies, porque de antemão pressupõe-se o conhecimento destas; a necessidade é de enquadrar os eventos na(s) espécie(s).

$\mathrm{Na}$ estrutura de enumeração das partes, chamado também de argumento por divisão, o orador possui o ônus de enumerar exaustivamente os componentes do todo, a fim de fortalecer suas razões para um determinado argumento.

O argumento por divisão constitui a base do dilema, que ocorre quando apenas duas opções são oferecidas e, escolhida qualquer destas, chega-se a conduta ou opinião de mesmo alcance, por uma das seguintes razões: 1 . Conduzem cada qual a um mesmo resultado; 2 . Conduzem a dois resultados de igual valor; 3. Acarretam, em cada caso, uma incompatibilidade com uma regra à qual se estava vinculado.

\subsection{Argumentos baseados na estrutura do real}

\subsubsection{O vínculo causal}

Ocorre quando se alega um "juízo de realidade" ou "juízo de verdade" admitido para estabelecer solidariedade entre estes e outros ${ }^{42}$. Contudo, a base desse tipo de argumento não serão as estruturas lógicas - como nos argumentos quaselógicos - mas sim o que se aceita como "real", "verdadeiro", "existente".

Esse tipo de argumento pode possuir dois tipos de ligação: as ligações de sucessão, que unem um fenômeno a suas consequências ou causas; e as ligações de coexistência, que unem pessoas a seus atos, um grupo aos indivíduos que dele fazem parte e uma essência a suas manifestações.

A ideia de vínculo entre "causa e efeito" é muito persuasiva, principalmente por conta da influência que as ciências naturais possuem sobre as demais ciências e

42 PERELMAN, Chaïm; OLBRECHTS-TYTECA, Lucie. Tratado da Argumentação: a Nova Retórica. 2005, p. 297. 
PARINI, Pedro; DE ABREU, Dã Filipe Santos. As estratégias retóricas na argumentação jurídica: estudo de caso da ação cautelar no 4039/DF. Revista Eletrônica Direito e Política, Programa de PósGraduação Stricto Sensu em Ciência Jurídica da UNIVALI, Itajaí, v.14, n.1, 10 quadrimestre de 2019. Disponível em: www.univali.br/direitoepolitica - ISSN 1980-7791

também em razão da predisposição natural que temos para ligar um antecedente a um consequente e criar vínculos de causalidade entre eventos. Esse tipo de argumento pode ser subdividido em categorias:

a) Argumentos que tendem a relacionar dois acontecimentos sucessivos entre si por meio de um vínculo causal;

b) Argumentos que tendem a descobrir a existência de uma causa para determinado acontecimento;

c) Argumentos que tendem a evidenciar os efeitos que um acontecimento trará.

Nos argumentos do tipo "b", o orador tende a procurar uma explicação racional para cada ato humano, a fim de explicar porque aconteceu aquele resultado. Não é aceito, em geral, que as condutas sejam irracionais ou despropositadas. Uma faceta importante que esse tipo de argumentação assume é nos argumentos retrospectivos. $O$ orador, nesses casos, retira a premissa fática (causa) e aponta os efeitos que essa ausência causaria (novas consequências).

Os argumentos do tipo "c" são chamados também de argumentos pragmáticos, porque tendem a analisar uma determinada hipótese a partir dos efeitos que ela provocará. É a transferência dos juízos de valor das consequências para as causas.

Para invalidar este tipo de argumento, o adversário pode discordar da valoração dada às consequências (o argumento pragmático pode ser acusado de negar juízos morais); ou pode atacar o próprio vínculo causa-efeito, afirmando que as causas alegadas não geram aquele efeito, mas outro.

O argumento pragmático também tem a condição de, ao firmar as boas consequências, advogar pela correção ou verdade de uma tese. No argumento pragmático, o sucesso se torna um critério de validade e objetividade de algumas teses.

Os argumentos do tipo "a" são os clássicos representantes dos argumentos de causa-efeito, visto que tendemos a admitir que todo evento gera algum efeito 
PARINI, Pedro; DE ABREU, Dã Filipe Santos. As estratégias retóricas na argumentação jurídica: estudo de caso da ação cautelar no 4039/DF. Revista Eletrônica Direito e Política, Programa de PósGraduação Stricto Sensu em Ciência Jurídica da UNIVALI, Itajaí, v.14, n.1, 10 quadrimestre de 2019. Disponível em: www.univali.br/direitoepolitica - ISSN 1980-7791

posterior.

\subsubsection{A pessoa e seus atos}

Ao argumentar com base na pessoa, agrupamos a ela qualidades, atos, defeitos, imagens e expectativas para fazê-la o centro de um feixe de relações e fenômenos aos quais ela dá significado. É como se "congelássemos" o indivíduo a partir dos eventos externos que a ele estão relacionados.

Essa imagem da pessoa ajuda na hora de argumentar contra ou a favor dela, mas a possibilidade que o ser humano tem de se transformar e de agir fora dos padrões esperados é o que dá sentido à moral e ao direito, enquanto expectativas futuras de adequação de conduta, e impede o uso do argumento consequencialista contra os seres humanos ${ }^{43}$.

Moral e direito julgam tanto a pessoa como o ato por ela praticado, porque admitem que a característica e os atos de alguém vão além de uma relação simples como a dos objetos com suas características. Espera-se que, se fulano agiu de maneira desonesta hoje, nada impedirá que ele aja desonestamente amanhã, porque os atos revelariam a "essência" de fulano, quem ele é diariamente ${ }^{44}$.

\subsubsection{0 argumento de autoridade}

O argumento de autoridade é a espécie mais destacada dos argumentos baseados no prestígio. Esse argumento consiste em afirmar (ou infirmar) uma tese porque outras pessoas (ou obras) o fazem, invocando somente a autoridade que estes últimos têm.

O positivismo científico se colocou totalmente contrário a esse tipo de argumento, porque um dos pressupostos do racionalismo moderno era

\footnotetext{
43 PERELMAN, Chaïm; OLBRECHTS-TYTECA, Lucie. Tratado da Argumentação: a Nova Retórica. p. 334-335.

${ }^{44}$ PERELMAN, Chaïm; OLBRECHTS-TYTECA, Lucie. Tratado da Argumentação: a Nova Retórica. p. 339-340.
} 
PARINI, Pedro; DE ABREU, Dã Filipe Santos. As estratégias retóricas na argumentação jurídica: estudo de caso da ação cautelar no 4039/DF. Revista Eletrônica Direito e Política, Programa de PósGraduação Stricto Sensu em Ciência Jurídica da UNIVALI, Itajaí, v.14, n.1, 10 quadrimestre de 2019. Disponível em: www.univali.br/direitoepolitica - ISSN 1980-7791

"verificabilidade empírica" das hipóteses, rejeitando-se aquilo que não pode ser submetido ao teste do método. No direito, contudo, o intérprete está condicionado (no sentido da hermenêutica filosófica gadameriana) pela tradição, pela jurisprudência e pela doutrina, de forma que o argumento de autoridade é essencial para a resolução de conflitos ${ }^{45}$.

Em muitas ocasiões, a crítica não é dirigida ao argumento de autoridade, mas à autoridade invocada. Dessa forma, quando um advogado rejeita um precedente suscitado pelo adversário, mas indica um outro que deve ser seguido no caso, o que este advogado fez foi rejeitar a autoridade trazida pelo seu adversário e apontar uma outra vista como mais adequada ao caso ${ }^{46}$.

As autoridades podem ser diversas: pessoas (Aristóteles, Machado de Assis, Rui Barbosa), textos (Código de Hamurabi, a Pedra de Roseta, o Corão), categorias de pessoas (os médicos, os cientistas, os teólogos) ou autoridades impessoais (a física, a religião, o direito).

Às vezes, a alegação de ignorância é uma forma de argumento de autoridade. Acontece, por exemplo, quando um especialista de renome em determinada área afirma: é impossível solucionar este caso. Esta afirmação implica que qualquer esforço posterior de resolução é inútil, porque a autoridade disse que assim é.

A ignorância também pode fortalecer o argumento, a depender do ignorante. É o caso do testemunho de uma criança: o fato dela ser ignorante pode conferir credibilidade ao que disser, já que não lhe seria possível manipular o testemunho ${ }^{47}$.

\subsubsection{Argumentos concernentes às diferenças de grau e de ordem}

O conhecido lugar comum do mais ou menos, e a separação de elementos em

\footnotetext{
45 PERELMAN, Chaïm; OLBRECHTS-TYTECA, Lucie. Tratado da Argumentação: a Nova Retórica. p. 348-349.

${ }^{46}$ PERELMAN, Chaïm; OLBRECHTS-TYTECA, Lucie. Tratado da Argumentação: a Nova Retórica. p. 349-350.

47 PERELMAN, Chaïm; OLBRECHTS-TYTECA, Lucie. Tratado da Argumentação: a Nova Retórica. p. 352-353.
} 
PARINI, Pedro; DE ABREU, Dã Filipe Santos. As estratégias retóricas na argumentação jurídica: estudo de caso da ação cautelar no 4039/DF. Revista Eletrônica Direito e Política, Programa de PósGraduação Stricto Sensu em Ciência Jurídica da UNIVALI, Itajaí, v.14, n.1, 10 quadrimestre de 2019. Disponível em: www.univali.br/direitoepolitica - ISSN 1980-7791

categorias, são trabalhados por Perelman nas diferenças entre grau e ordem.

As diferenças de ordem são as que se utilizam de hierarquias qualitativas, e elas partem do pressuposto de que os dois (ou mais) itens em comparação possuem naturezas distintas, são elementos distantes entre $\mathrm{si}^{48}$. Desse modo, ao dizer que os seres humanos são mais altos que as formigas, o orador iguala os seres humanos de um lado (ainda que haja discrepâncias de altura dentro dessa categoria) e os separa das formigas, as quais ficam igualadas entre si do outro lado (ainda que haja muitas diferenças entre estas).

Já as diferenças de grau são as que utilizam hierarquias quantitativas, e pressupõe que os itens em comparação possuem uma mesma natureza, e o que os distingue é apenas a intensidade ou quantidade dessa característica ${ }^{49}$. Desse modo, pode-se fazer um gráfico contendo a altura de diversas espécies de formigas e de diversos seres humanos, sem separar a priori humanos e formigas.

Um bom exemplo para demonstrar a força do argumento de ordem é o seguinte: "não há diferença entre desviar milhões de reais ou subornar um guarda; tudo isso é corrupção". Aqui, usa-se uma diferença de ordem entre honestidade e desonestidade, sem espaço para gradações.

O exemplo contrário é: "não podemos nivelar aquele que pratica pequena corrupção, como pegar uma caneta da repartição pública, com o que desvia milhões de reais e provoca os males de nossa sociedade". Nesta situação, percebemos um reforço da diferença de grau entre honestidade e desonestidade, a fim de demonstrar que há pessoas "mais desonestas" que outras.

Por fim, é por meio da argumentação que se define o momento em que uma diferença de grau se transformará em diferença de ordem. Por exemplo: quantos fios de cabelo precisam cair para que se considere calvo um cabeludo?

\footnotetext{
48 PERELMAN, Chaïm; OLBRECHTS-TYTECA, Lucie. Tratado da Argumentação: a Nova Retórica. p. 393.

49 PERELMAN, Chaïm; OLBRECHTS-TYTECA, Lucie. Tratado da Argumentação: a Nova Retórica. p. 393.
} 
PARINI, Pedro; DE ABREU, Dã Filipe Santos. As estratégias retóricas na argumentação jurídica: estudo de caso da ação cautelar no 4039/DF. Revista Eletrônica Direito e Política, Programa de PósGraduação Stricto Sensu em Ciência Jurídica da UNIVALI, Itajaí, v.14, n.1, 10 quadrimestre de 2019. Disponível em: www.univali.br/direitoepolitica - ISSN 1980-7791

\section{A análise retórica da decisão judicial}

\subsection{Caso concreto: a Ação Cautelar no 4039/DF}

Após apresentar, mesmo que sucintamente, nosso marco teórico, cumpre narrar o caso escolhido para a análise retórica proposta, a Ação Cautelar (AC) no 4039/DF.

Os fatos narrados pelo Ministério Público Federal (MPF), copiados na decisão pelo julgador, relatam que Delcídio do Amaral prometera a Nestor Cerveró - delator da Operação Lava-Jato - benefícios financeiros e uso de seu prestígio político para convencer ministros do STF a concederem habeas corpus ao delator; em troca, exigia que não celebrasse acordo de colaboração premiada com o MPF; ou que Cerveró ocultasse a participação do senador no esquema de corrupção delatado. Também prometera a Cerveró, concedido ou não o habeas corpus, elaborar plano de fuga deste à Espanha, visto que Cerveró tem nacionalidade espanhola e lá estaria a salvo da jurisdição penal brasileira.

Partindo da procedência desses eventos e relatando-os como fatos, a conduta do senador terminou por ser enquadrada pela acusação no Art. $2^{\circ}, \S 1^{\circ}$ e $\S 4^{\circ}$, II, da Lei no $12.850 / 12^{50}$, tendo sido também requerida a sua prisão cautelar, com fundamento nos arts. 312, caput, e 313, I, ambos do Código de Processo Penal (CPC), sob a alegação de que esta seria a única medida possível para impedir que Amaral continuasse a interferir nas investigações do parquet.

Nosso intuito, a partir de agora, é aplicar a metodologia de análise retórica proposta por Ballweg para examinar os argumentos usados no caso pelo julgador, levando em consideração a subdivisão da retórica analítica proposta pelo autor

50 Art. 2o Promover, constituir, financiar ou integrar, pessoalmente ou por interposta pessoa, organização criminosa: Pena - reclusão, de 3 (três) a 8 (oito) anos, e multa, sem prejuízo das penas correspondentes às demais infrações penais praticadas.

$\S 1$ 을 mesmas penas incorre quem impede ou, de qualquer forma, embaraça a investigação de infração penal que envolva organização criminosa.

§ 40 A pena é aumentada de 1/6 (um sexto) a 2/3 (dois terços): II - se há concurso de funcionário público, valendo-se a organização criminosa dessa condição para a prática de infração penal; 
PARINI, Pedro; DE ABREU, Dã Filipe Santos. As estratégias retóricas na argumentação jurídica: estudo de caso da ação cautelar no 4039/DF. Revista Eletrônica Direito e Política, Programa de PósGraduação Stricto Sensu em Ciência Jurídica da UNIVALI, Itajaí, v.14, n.1, 10 quadrimestre de 2019. Disponível em: www.univali.br/direitoepolitica - ISSN 1980-7791

alemão. Dessa forma, separamos as estruturas de argumentos a partir de um ponto de vista fronético e holístico.

\subsection{Análise fronética}

\subsubsection{Análise agôntica das relações entre os sujeitos envolvidos na situação retórica: o uso estratégico do argumento de autoridade e a regra de justiça}

O ponto de partida da análise fronética serão as falas do sujeito emissor do discurso - o ministro Teori Zavascki.

No que concerne ao aspecto agôntico da análise retórica, que leva em consideração as relações de interação entre os sujeitos do discurso, podemos entender que o auditório imediato do ministro eram os outros membros da $2^{a}$ Turma do STF - porque eles iriam referendar sua decisão. Podemos inferir que a outra audiência a que se dirigem as falas são os interessados imediatos: o Ministério Público Federal - que pediu a prisão - e o senador, enquanto réu.

Quanto à relação agôntica com os outros ministros, a estratégia do relator, enquanto sujeito ativo na produção de seu discurso, é utilizar o argumento de autoridade - a autoridade, no caso, advém do próprio peso institucional do STF e a regra de justiça - porque os casos iguais devem ser tratados de maneira igual; ambas as estratégias se mostram no uso de precedentes do próprio Supremo para sedimentar as premissas da decisão. Em alguns desses outros casos, o relator era o próprio Zavascki.

Temos esse tipo de argumento quando ele discorre sobre a natureza e os requisitos da prisão preventiva ${ }^{51}$, referindo-se a dois Habeas Corpus julgados pela Segunda Turma em que ele próprio fora o relator; quando confirma a licitude das provas colhidas pelo MPF; quando ressalta que os fatos narrados se

51 BRASIL. Supremo Tribunal Federal. Ação Cautelar no 4039. Requerente: Ministério Público Federal. Relator: Teori Zavascki. Brasília, 24 de Novembro de 2015. Disponível em http://www.stf.jus.br/arquivo/cms/noticiaNoticiaStf/anexo/Acao_Cautelar_4039.pdf acessado em $06 / 06 / 17$ às $15: 43$. p. $15-17$ 
PARINI, Pedro; DE ABREU, Dã Filipe Santos. As estratégias retóricas na argumentação jurídica: estudo de caso da ação cautelar no 4039/DF. Revista Eletrônica Direito e Política, Programa de PósGraduação Stricto Sensu em Ciência Jurídica da UNIVALI, Itajaí, v.14, n.1, 10 quadrimestre de 2019. Disponível em: www.univali.br/direitoepolitica - ISSN 1980-7791

enquadram nas hipóteses de decretação de custódia cautelar - por representarem risco à instrução criminal em razão da interferência no depoimento de testemunhas e na produção de provas; e porque as constantes tentativas de acobertar crimes constituem atentados contra a ordem pública ${ }^{52}$.

Quando analisa a possibilidade de prisão preventiva especificamente decretada contra Senador da República, ele propõe um argumento de simetria (classificado como quase-lógico) junto ao argumento de autoridade, ao evocar voto proferido pela ministra Cármen Lúcia ${ }^{53}$ no HC 89.417-8, julgado no STF, em que fora autorizada a prisão preventiva de parlamentares do Estado de Rondônia.

Ainda do ponto de vista agôntico, no que concerne à relação ministro-MPF e ministro-réu, é interessante perceber que a primeira parte do decisum (páginas 1 a 15) é uma cópia de trechos da petição ministerial, na qual o MPF apresenta transcrições de gravações telefônicas e depoimentos que denotam várias possíveis condutas criminosas praticadas pelo senador Delcídio do Amaral em conjunto com outras pessoas, com o objetivo de impedir que Amaral fosse implicado no esquema de corrupção da Petrobras e que a Operação Lava-Jato o investigasse; também há os argumentos dogmáticos para a decretação da prisão preventiva.

No momento dedicado à fundamentação, Zavascki copia diversos trechos da inicial do MPF, nos quais são detalhados mais fatos que corroboram a tese de que o senador estava trabalhando para impedir o prosseguimento do processo penal contra si ${ }^{54}$.

Nas duas situações descritas nos parágrafos anteriores, é usado o argumento de ligação ato-pessoa - baseado na estrutura do real - para demonstrar a probabilidade de evasão da justiça penal, mas a estratégia do ministro é usar duas falas diferentes para reforçar a conclusão: a do MPF, transcrita literalmente,

\footnotetext{
52 BRASIL. Supremo Tribunal Federal. Ação Cautelar no 4039, p. 26; 31-32.

53 BRASIL. Supremo Tribunal Federal. Ação Cautelar no 4039, p. 37-39.

54 BRASIL. Supremo Tribunal Federal. Ação Cautelar no 4039, p. 17-34.
} 
PARINI, Pedro; DE ABREU, Dã Filipe Santos. As estratégias retóricas na argumentação jurídica: estudo de caso da ação cautelar no 4039/DF. Revista Eletrônica Direito e Política, Programa de PósGraduação Stricto Sensu em Ciência Jurídica da UNIVALI, Itajaí, v.14, n.1, 10 quadrimestre de 2019. Disponível em: www.univali.br/direitoepolitica - ISSN 1980-7791

e a dele próprio - na qual sempre se diz que "em tese" há cometimento de fato criminoso.

Com isso, em relação ao senador e aos outros ministros, o ministro Zavascki, na qualidade de orador (para se usar um termo técnico da retórica clássica), isto é, autor do discurso, constroi uma postura de neutralidade do julgamento, já que não é ele, mas o Ministério Público, quem afirma que são impróprias as condutas do réu; o ministro, por isso mesmo, se vale de uma linguagem aparentemente neutra, empregando expressões como "em tese" e "possivelmente". E reforça sua equidistância ao supostamente "demonstrar" que os pressupostos jurídicos tomados para decidir não são criação sua, mas interpretações e conclusões sedimentadas no próprio Supremo.

Em relação ao parquet, o ministro prestigia o órgão da acusação, já que "acredita" na narração ministerial e nos elementos de prova colhidos, e a partir deles concede o pedido de prisão.

\subsubsection{Análise ergôntica dos efeitos da manipulação dos objetos por parte do sujeito discursivo: os institutos jurídicos se adequam às finalidades do decisor}

Este âmbito da análise fronética tem como finalidade expor e examinar o modo pelo qual o sujeito autor do discurso manipula o objeto de seu logos no contexto da tradicional relação sujeito-objeto. Levando em consideração as inúmeras teses construtivistas da epistemologia contemporânea, é possível afirmar que os argumentos produzidos em um discurso são fundamentais na constituição disso que comumente se chama de realidade e que, de nosso ponto de vista teórico, chamamos de retórica material.

O papel institucional que uma entidade como o STF representa na determinação do sentido que as expressões textuais irão assumir por meio de suas interpretações diante de casos concretos que devem ser decididos é fundamental no processo de constituição da própria realidade do direito. Ou seja, a jurisprudência de um órgão como o STF enquanto titular do exercício de violência simbólica é responsável por boa parte do processo de concretização dos 
PARINI, Pedro; DE ABREU, Dã Filipe Santos. As estratégias retóricas na argumentação jurídica: estudo de caso da ação cautelar no 4039/DF. Revista Eletrônica Direito e Política, Programa de PósGraduação Stricto Sensu em Ciência Jurídica da UNIVALI, Itajaí, v.14, n.1, 10 quadrimestre de 2019. Disponível em: www.univali.br/direitoepolitica - ISSN 1980-7791

institutos jurídicos.

O primeiro objeto de que trata Zavascki em sua decisão é o instituto da "prisão preventiva". Para caracterizá-la, sua base de argumentos foi constituída mais uma vez pela regra de justiça aplicada em conjunto com o argumento de autoridade, a partir de precedentes do STF (mencionados quando da análise agôntica); e o método de interpretação literal dos arts. 312, 319 e 282, § 60, todos do Código de Processo Penal.

O relator define que a prisão preventiva, por atentar contra a presunção de inocência e por se constituir na medida cautelar mais extrema, só é legítima quando "for o único meio eficiente para preservar os valores jurídicos que a lei penal visa proteger, segundo o art. 312 do Código de Processo Penal"55.

Sua segunda premissa é que não basta apenas provar a existência do delito e os indícios de autoria. É necessário que se demonstre a presença de um dos quatro requisitos autorizadores previstos no artigo 312 do CPP: a) a garantia da ordem pública; b) a garantia da ordem econômica; c) a conveniência da instrução criminal; d) a segurança da aplicação da lei penal ${ }^{56}$.

Percebe-se como os requisitos do art. 312 do CPP são elásticos do ponto de vista semântico, permitindo justamente a manobra mais fundamental da produção dogmática do direito que é o jogo de esticar-e-encolher dos métodos de interpretação extensiva e restritiva. A dogmática hermenêutica tornou-se contemporaneamente a parte mais visível dos métodos que compõem o processo de produção do direito. A concretização do sentido destas figuras próprias da dogmática jurídica: "ordem pública", "ordem econômica", "conveniência" e "segurança", depende inexoravelmente do trabalho de atribuição de significados pelo juiz ou pelos juízes da causa a essas expressões textuais. O sentido representa a própria efetividade destas entidades dogmáticas que obviamente não existem no mundo físico enquanto "dados" da realidade. São construções

55 BRASIL. Supremo Tribunal Federal. Ação Cautelar no 4039, p. 15-16.

56 BRASIL. Supremo Tribunal Federal. Ação Cautelar no 4039, p. 16. 
PARINI, Pedro; DE ABREU, Dã Filipe Santos. As estratégias retóricas na argumentação jurídica: estudo de caso da ação cautelar no 4039/DF. Revista Eletrônica Direito e Política, Programa de PósGraduação Stricto Sensu em Ciência Jurídica da UNIVALI, Itajaí, v.14, n.1, 10 quadrimestre de 2019. Disponível em: www.univali.br/direitoepolitica - ISSN 1980-7791

que dependem dos argumentos que as fundamentam.

O terceiro requisito para decretação da preventiva é que não haja outro meio menos grave de preservar os bens jurídicos penais ${ }^{57}$. Aqui o topos geral do mais e do menos, que são as diferenças de grau e ordem catalogadas por Perelman, está presente no próprio texto normativo. A avaliação da gravidade parece ser passível de quantificação como se a atribuição de pesos a cada uma das medidas cautelares fosse algo possível. É a típica transformação do qualitativo em quantitativo. Além disso, a ambiguidade da expressão "bem jurídico", no âmbito do direito penal, é um material rico para o desenvolvimento das mais diversas formas de argumentação.

Para corroborar suas premissas, cita o relator que os três requisitos têm sido reiteradamente afirmados na jurisprudência do Supremo, e colaciona ementa do acórdão proferido no HC no $95.290^{58}$ - novamente uso do argumento de autoridade juntamente com a regra de justiça.

O segundo objeto que o julgador manipula é a lei no $12.850 / 13$. Ele sedimenta que o crime constante do art. $1^{0}, \S 1^{0}$, desta lei ${ }^{59}$ é crime permanente, e por isso pode haver flagrante a qualquer tempo. O fundamento é a regra de justiça junto com o argumento de autoridade, já que há decisões do Supremo sobre a matéria60; e afirma que o crime é inafiançável, conforme o art. 324, IV, do CPP61 - argumento quase-lógico, porque faz uso do entimema - o "silogismo retórico".

O terceiro objeto a ser manejado no julgamento é a imunidade processual

57 BRASIL. Supremo Tribunal Federal. Ação Cautelar no 4039, p. 16.

58 BRASIL. Supremo Tribunal Federal. Ação Cautelar no 4039, p. 16-17.

59 Art. 1o [...] § $1^{\circ}$ Considera-se organização criminosa a associação de 4 (quatro) ou mais pessoas estruturalmente ordenada e caracterizada pela divisão de tarefas, ainda que informalmente, com objetivo de obter, direta ou indiretamente, vantagem de qualquer natureza, mediante a prática de infrações penais cujas penas máximas sejam superiores a 4 (quatro) anos, ou que sejam de caráter transnacional.

60 BRASIL. Supremo Tribunal Federal. Ação Cautelar no 4039, p. 35.

61 Art. 324. Não será, igualmente, concedida fiança: [...] IV - quando presentes os motivos que autorizam a decretação da prisão preventiva 
PARINI, Pedro; DE ABREU, Dã Filipe Santos. As estratégias retóricas na argumentação jurídica: estudo de caso da ação cautelar no 4039/DF. Revista Eletrônica Direito e Política, Programa de PósGraduação Stricto Sensu em Ciência Jurídica da UNIVALI, Itajaí, v.14, n.1, 10 quadrimestre de 2019. Disponível em: www.univali.br/direitoepolitica - ISSN 1980-7791

parlamentar, prevista no art. 53, § 20, da Constituição ${ }^{62}$.

Inicialmente, utiliza um argumento quase-lógico de incompatibilidade de asserções, pois afirma que a regra não pode ser vista isoladamente, mas deve ser interpretada dentro do ordenamento constitucional brasileiro ${ }^{63}$. Portanto, devem ser compatibilizados o "Ordenamento Constitucional Brasileiro" e a "Imunidade Processual Parlamentar" por meio de uma interpretação sistemática de normas, método dogmático de interpretação que se destaca no contexto do direito moderno.

Para fixar qual o sentido adequado para o instituto da imunidade, o relator propõe um argumento de simetria, ao evocar voto proferido pela ministra Cármen Lúcia ${ }^{64}$ no HC 89.417-8, julgado no STF, em que fora autorizada a prisão preventiva de parlamentares do Estado de Rondônia; o ministro não argumenta sobre os pontos em comum e a aplicabilidade do precedente ao caso novamente utilizando o entimema em sua argumentação; ele repete trecho do voto, o qual analisaremos para entender a estrutura argumentativa aplicada.

O voto copiado inicia dizendo que aplicar isoladamente o art. 52, §§ $2^{\circ}$ e $3^{\circ}$, da Constituição, sem levar em conta o sistema constitucional em sua inteireza, conduziria ao oposto do que se tem enquanto princípios e fins do ordenamento jurídico. É o uso da incompatibilidade de asserções que se aproveita da completa ausência de um sentido unívoco ou de um acordo sobre quais seriam os fins do ordenamento jurídico. Com esta estratégia, o argumento ganha força sem que a ministra tenha que fazer afirmações mais precisas e, por consequência, comprometedoras e reveladoras de suas ideologias.

Contudo, a Ministra relatora usa esse tipo de argumento com uma atitude lógica,

62 Art. 53. [...] $\S 20$ Desde a expedição do diploma, os membros do Congresso Nacional não poderão ser presos, salvo em flagrante de crime inafiançável. Nesse caso, os autos serão remetidos dentro de vinte e quatro horas à Casa respectiva, para que, pelo voto da maioria de seus membros, resolva sobre a prisão. (Redação dada pela Emenda Constitucional no 35, de 2001)

${ }^{63}$ BRASIL. Supremo Tribunal Federal. Ação Cautelar no 4039, p. 36-37.

${ }^{64}$ BRASIL. Supremo Tribunal Federal. Ação Cautelar no 4039, p. 37-39. 
PARINI, Pedro; DE ABREU, Dã Filipe Santos. As estratégias retóricas na argumentação jurídica: estudo de caso da ação cautelar no 4039/DF. Revista Eletrônica Direito e Política, Programa de PósGraduação Stricto Sensu em Ciência Jurídica da UNIVALI, Itajaí, v.14, n.1, 10 quadrimestre de 2019. Disponível em: www.univali.br/direitoepolitica - ISSN 1980-7791

porque discorre longamente sobre os motivos de, no caso que ela analisa, haver incompatibilidade entre a imunidade parlamentar e o princípio da cidadania e o republicano.

Explica a ministra que o princípio da imunidade parlamentar (tratado no art. 53, $\S \S 2^{\circ}$ e $\left.3^{\circ}, \mathrm{CF}\right)$ continua íntegro e obrigatório, como forma de garantir a autonomia das instituições e daqueles que ocupam os cargos destas; contudo, na hipótese, há situação de anormalidade institucional ${ }^{65}$, porque 23 dos 24 parlamentares do estado de Rondônia estavam sendo processados e havia fortes indícios de que uma organização criminosa tomara as rédeas do legislativo daquele Estado da federação. Desta forma, numa situação de anormalidade institucional não se poderiam aplicar regras que foram concebidas para situações de normalidade. Afirma a ministra que "à excepcionalidade do quadro há de corresponder a excepcionalidade da forma de interpretar e aplicar os princípios e regras do sistema constitucional"66.

O trecho copiado termina com um argumento consequencialista (argumento baseado na estrutura do real), porque a ministra alega que aplicar uma regra protetiva a alguém que não respeita suas prerrogativas "seria um álibi permanente e intocável dado pelo sistema àquele que pode sequer não estar sendo mais titular daquela condição, a não ser formalmente" ${ }^{\prime 67}$.

\subsubsection{Análise pitanêutica da manipulação dos conceitos linguísticos da dogmática jurídica: o sentido não-literal do conceito de imunidade parlamentar}

65 O HC 89.417-8 tinha como paciente o então Presidente da Assembleia Legislativa de Rondônia, cuja prisão havia sido decretada pelo Superior Tribunal de Justiça. O parlamentar alegava que não subsistiam motivos para continuar preso, porque não houvera flagrante de crime inafiançável e porque a Casa Legislativa de que fazia parte não tinha sido comunicada para que resolvesse sobre a prisão (o art. $27, \S 10, \mathrm{CF}$, determina que as regras sobre imunidades e inviolabilidades se estendem aos parlamentares estaduais). É, em linhas gerais, o caso de que está tratando a ministra Cármen Lúcia.

${ }^{66}$ BRASIL. Supremo Tribunal Federal. Ação Cautelar no 4039, p. 38.

67 BRASIL. Supremo Tribunal Federal. Ação Cautelar no 4039, p. 39. 
PARINI, Pedro; DE ABREU, Dã Filipe Santos. As estratégias retóricas na argumentação jurídica: estudo de caso da ação cautelar no 4039/DF. Revista Eletrônica Direito e Política, Programa de PósGraduação Stricto Sensu em Ciência Jurídica da UNIVALI, Itajaí, v.14, n.1, 10 quadrimestre de 2019. Disponível em: www.univali.br/direitoepolitica - ISSN 1980-7791

Talvez o conceito mais importante que o julgador precisava moldar é o de "imunidade parlamentar", conforme positivado no art. 53, §20, da Constituição. Para fazê-lo de modo eficaz, seria necessário interpretar criativamente o dispositivo constitucional.

O modo como esse signo linguístico é trabalhado pelo utente da língua constitui o enfoque da pitanêutica. No caso em tela, para afastar a interpretação literal do dispositivo, o argumento do ministro é de que "a própria realidade, porém, vem demonstrando que também o sentido dessa norma constitucional não pode decorrer de interpretação isolada"68. Perceba-se que, na fala de Zavascki, "a realidade" é quem determina que se faça uma interpretação sistemática embora ele não explique que realidade é esta - como se houvesse uma dependência da linguagem em relação aos dados reais do mundo físico e espiritual.

Como forma de exemplificar que esse tipo de interpretação já fora feita, é usado trecho do voto da Ministra Cármen Lúcia no HC no 89417. O objetivo é mostrar que o texto constitucional deve ser lido de uma maneira "que conduza à aplicação efetiva e eficaz do sistema constitucional como um todo"69, ou seja, deve ser interpretado sistematicamente.

Aqui, o precedente do STF não é a fonte de autoridade da decisão. Ele é só um exemplo de como deve ser interpretado o texto constitucional; a autoridade que determina essa interpretação é "a realidade".

Ao observarmos a construção acima, notamos que a palavra "realidade" é "objetivizada". É um argumento ontológico, baseado na estrutura do real, que toma como pressuposto uma realidade inequívoca que todos - aqui entendidos como "a sociedade" ou "as pessoas" - compreendem ou podem compreender da mesma forma. Desta maneira, não se admitem possíveis divergências ou leituras alternativas dos fatos, e o ministro elimina traços de subjetividade própria, já

68 BRASIL. Supremo Tribunal Federal. Ação Cautelar no 4039, p. 36.

69 BRASIL. Supremo Tribunal Federal. Ação Cautelar no 4039, p. 36. 
PARINI, Pedro; DE ABREU, Dã Filipe Santos. As estratégias retóricas na argumentação jurídica: estudo de caso da ação cautelar no 4039/DF. Revista Eletrônica Direito e Política, Programa de PósGraduação Stricto Sensu em Ciência Jurídica da UNIVALI, Itajaí, v.14, n.1, 10 quadrimestre de 2019. Disponível em: www.univali.br/direitoepolitica - ISSN 1980-7791

que aquela não seria uma visão particular de uma pessoa específica - Teori Zavascki - mas uma "entidade" externa e contra a qual não se pode debater.

Após discorrer sobre o modo como os objetos da decisão foram fixados, estes objetos ganham a primazia no discurso persuasivo, e nos conduzem à próxima esfera da análise retórica.

\subsection{Análise holotática}

\subsubsection{Análise ontotática dos objetos que compõem a retórica material do direito}

Esta estratégia de apontar a realidade como algo independente dos sujeitos e válido em si mesmo é justamente o que se analisa no âmbito da ontotática, que faz parte da análise holotática.

A holotática se concentra no exame das relações retóricas a partir dos objetos que formam a retórica material enquanto a própria realidade dos sentidos reificados por meio de argumentos. No caso em tela, podemos distinguir dois tipos de objetos do discurso: aqueles que o relator fixou, conforme mostrado na análise ergôntica; e os fatos atribuídos ao réu. A partir dos requisitos autorizadores da prisão preventiva, o relator lança seu olhar sobre as condutas atribuídas ao réu, afirmando que "à luz de tais premissas é que se examina o presente requerimento"70. A partir de então, o ministro Zavascki elenca várias condutas (nas páginas 17-34) que preencheriam os três requisitos por ele fixados.

Ontotaticamente, temos que um objeto (os requisitos autorizadores da prisão preventiva) define o outro objeto (as ações atribuídas ao acusado) porque estas passam a ser condutas materialmente delitivas e potencialmente prejudiciais à aplicação da lei penal e à ordem pública, as quais autorizam a concessão do pedido de encarceramento.

70 BRASIL. Supremo Tribunal Federal. Ação Cautelar no 4039, p. 17. 
PARINI, Pedro; DE ABREU, Dã Filipe Santos. As estratégias retóricas na argumentação jurídica: estudo de caso da ação cautelar no 4039/DF. Revista Eletrônica Direito e Política, Programa de PósGraduação Stricto Sensu em Ciência Jurídica da UNIVALI, Itajaí, v.14, n.1, 10 quadrimestre de 2019. Disponível em: www.univali.br/direitoepolitica - ISSN 1980-7791

Ao confrontar os outros dois objetos (o instituto da imunidade parlamentar e a Lei no 12.850/13) com os fatos que tem diante de si (também objetos), o relator opta primeiro por uma interpretação literal do art. 53, $2^{\circ}, \mathrm{CF}$, e sustenta a flagrância e inafiançabilidade do crime.

Para caracterizar a flagrância, o ministro apela para a regra de justiça (argumento quase-lógico), visto que o próprio Supremo havia declarado que o crime previsto no art. $2^{\circ}$ da Lei $12.850 / 13$ é caracterizado como permanente; dessa forma, sendo crime permanente, ele possui execução continuada e o réu o estava praticando no momento em que foi pego ${ }^{71}$; para caracterizar a inafiançabilidade, ele afirma que esta decorre do art. 324, IV, do Código de Processo Penal72.

Mais à frente, o relator irá tomar a realidade (objeto) como preponderante para determinar o sentido do art. 53, $\S 20$, da CF (objeto), pois afirma que a interpretação dessa regra constitucional não ocorre isoladamente, e que os fatos são muito graves e exigem uma interpretação mais condizente com a realidade que se está encarando73, e a partir daí invoca a decisão do Supremo no HC no 89.417-8 para dar novo sentido ao texto constitucional, utilizando o argumento de simetria junto com o de autoridade.

\subsubsection{Análise teleotática de como a posição dos sujeitos é determinada a partir dos objetos que colocam diante de si}

No plano teleotático, pode-se observar um uso recorrente da ligação ato-pessoa - argumento baseado na estrutura do real - para definir o caráter do réu (sujeito) a partir das condutas que Ihe são atribuídas (objeto).

E se acresce ainda um argumento do tipo grupo-membro (baseado na estrutura do real), ao afirmar que o crime em tela assume muito maior gravidade, porque atentaria contra o Tribunal competente para julgamento (STF) - relação objeto-

\footnotetext{
71 BRASIL. Supremo Tribunal Federal. Ação Cautelar no 4039, p. 35.

72 BRASIL. Supremo Tribunal Federal. Ação Cautelar no 4039, p. 35.

73 BRASIL. Supremo Tribunal Federal. Ação Cautelar no 4039, p. 36-37.
} 
PARINI, Pedro; DE ABREU, Dã Filipe Santos. As estratégias retóricas na argumentação jurídica: estudo de caso da ação cautelar no 4039/DF. Revista Eletrônica Direito e Política, Programa de PósGraduação Stricto Sensu em Ciência Jurídica da UNIVALI, Itajaí, v.14, n.1, 10 quadrimestre de 2019. Disponível em: www.univali.br/direitoepolitica - ISSN 1980-7791

sujeito. Ou seja, o relator diz que esse crime específico vai além, no que tange à periculosidade, do grupo dos crimes comuns ${ }^{74}$.

O argumento acima é um dos suportes para que o ministro entenda por afastar a interpretação literal do art. 53, $2^{\circ}$, da Constituição, e opte por interpretá-lo sistematicamente e autorizar a prisão preventiva do senador.

\subsubsection{Análise axiotática das estratégias de reificação dos conceitos linguísticos}

Como dito mais acima, a axiotática está focada nas relações entre os objetos e os sinais, com a prevalência daqueles sobre estes. Neste domínio, os nomes passam a ter relação de dependência com aquilo a que se referem, e seu uso não pode ser alterado porque eles são "aquela coisa".

No caso em análise, não percebemos essa relação ao longo da decisão. Os argumentos do ministro não passam por esse tipo de "monossignificação das palavras" e nem por uma relação única entre algum signo e seu significado.

Como hipótese, podemos supor que a atribuição de relação única entre significante e significado não é usada porque se trata de um caso raro - não é comum pedido de prisão preventiva de parlamentares; dessa forma, não há uma imbricação entre conceitos e objetos que seja relevante e precise ser usada pelo julgador, ou uma doutrina/jurisprudência consolidada sobre o tema e que tenha assentado as palavras que devem ser usadas.

\section{CONSIDERAÇÕES FINAIS}

No caso examinado, os fundamentos da decisão tomam por base argumentos de autoridade, principalmente para definição e conceptualização dos objetos da decisão. Estes argumentos de autoridade são entendimentos do próprio Supremo Tribunal Federal.

\footnotetext{
74 BRASIL. Supremo Tribunal Federal. Ação Cautelar no 4039, p. 37.
} 
PARINI, Pedro; DE ABREU, Dã Filipe Santos. As estratégias retóricas na argumentação jurídica: estudo de caso da ação cautelar no 4039/DF. Revista Eletrônica Direito e Política, Programa de PósGraduação Stricto Sensu em Ciência Jurídica da UNIVALI, Itajaí, v.14, n.1, 10 quadrimestre de 2019. Disponível em: www.univali.br/direitoepolitica - ISSN 1980-7791

Podemos a partir daí supor que um dos motivos para esse uso é a necessidade de mostrar que a decisão "inovadora" - prisão cautelar de senador - era decorrente da jurisprudência do próprio Supremo.

Por outro lado, é possível concordar com José Rodrigo Rodriguez ${ }^{75}$, o qual afirma que a jurisdição brasileira é formada com base no argumento de autoridade e na opinião dos tribunais e juízes, expressas por meio das súmulas e enunciados. Segundo o autor, não há um pensamento sistemático de reconstrução de argumentos, mas uma preocupação com o resultado do julgamento.

Além do uso constante de súmulas e entendimentos jurisprudenciais, o magistrado cola literalmente um voto proferido em outro processo, sem reconstruir os argumentos ou analisar as semelhanças entre os casos; nesta hipótese, o voto serve como argumento de autoridade.

Além disso, na análise pitanêutica percebemos que o magistrado usa o elemento "realidade" como uma entidade com vontade própria, que chega a determinar os métodos empregados na interpretação do texto constitucional.

Obviamente, esse é um meio de esconder a subjetividade do próprio ministro, de não explicitar que aquela é a sua vontade (ou opinião) sobre a melhor forma de interpretar o texto constitucional, ou seja, é uma tentativa de esconder a sua subjetividade.

Outro aspecto de destaque é que a maior parte da decisão é composta de relatos desfavoráveis ao réu, possivelmente para reforçar a ligação ato-pessoa e confirmar que se está tratando de alguém que fatalmente irá delinquir caso não seja impedido.

Essa ligação se torna ainda mais persuasiva porque o acusado é alguém que detém alto cargo na estrutura de poder da República, o que aumenta suas possibilidades de ação e alcance de suas condutas; e, no momento da decisão,

75 RODRIGUEZ, José Rodrigo. Como decidem as cortes: para uma crítica do direito (brasileiro). São Paulo: FGV editora, 2013, p. 7-8. 
PARINI, Pedro; DE ABREU, Dã Filipe Santos. As estratégias retóricas na argumentação jurídica: estudo de caso da ação cautelar no 4039/DF. Revista Eletrônica Direito e Política, Programa de PósGraduação Stricto Sensu em Ciência Jurídica da UNIVALI, Itajaí, v.14, n.1, 10 quadrimestre de 2019. Disponível em: www.univali.br/direitoepolitica - ISSN 1980-7791

não the fora dada oportunidade para se defender, de modo que o ministro não precisa confrontar relatos distintos sobre os mesmos eventos e pode assumir como verossímeis (ou plausíveis) as acusações do MPF.

Finalmente, observamos a possibilidade de aplicar a metodologia de Ballweg no estudo de decisões judiciais, algo até agora inédito. Como vemos acima, a divisão proposta pelo autor amplia as possibilidades para o analista do direito, porque fornece pontos de vista a partir do sujeito e do objeto, o que não é comum na área jurídica, a qual se prende aos aspectos semióticos, com primazia dos signos linguísticos.

\section{REFERÊNCIAS DAS FONTES CITADAS}

ADEODATO, João Maurício. A retórica constitucional. Sobre tolerância, direitos humanos e outros fundamentos éticos do direito positivo. São Paulo: Saraiva, 2010.

Saraiva, 2002.

Ética \& Retórica: para uma teoria da dogmática jurídica. São Paulo: . Retórica analítica da dogmática jurídica existencial e estratégica. Revista duc in altum. Caderno de Direito, vol. 4, nº 5, jan-jun. 2012.

ARISTÓTELES. Retórica. Trad. Manuel Alexandre Júnior, Paulo Farmhouse Alberto e Abel do Nascimento Pena. Lisboa: Imprensa Nacional - Casa da Moeda, 2005.

Tratados de Lógica (Órganon). Trad. Miguel Candel Sanmartín. Madrid: Gredos, 1998. Tomo I.

BALLWEG, Ottmar. Analytical rhetoric, semiotic and law. In: KEVELSON, Roberta. Law and semiotics. v. 1. New York: Plenum Press, 1987, p. 25-33.

Retórica analítica e direito. Tradução de J. M. Adeodato. Revista Brasileira de Filosofia, v. XXXIX, Fasc. 163, jul-ago-set, 1991b, p. 175-184.

BRASIL. Supremo Tribunal Federal. Ação Cautelar no 4039. Requerente: Ministério Público Federal. Relator: Teori Zavascki. Brasília, 24 de Novembro de $2015 . \quad$ Pág. 4-5 disponível em http://www.stf.jus.br/arquivo/cms/noticiaNoticiaStf/anexo/Acao_Cautelar_4039. pdf acessado em 06/06/17 às $15: 43$ 
PARINI, Pedro; DE ABREU, Dã Filipe Santos. As estratégias retóricas na argumentação jurídica: estudo de caso da ação cautelar no 4039/DF. Revista Eletrônica Direito e Política, Programa de PósGraduação Stricto Sensu em Ciência Jurídica da UNIVALI, Itajaí, v.14, n.1, 10 quadrimestre de 2019. Disponível em: www.univali.br/direitoepolitica - ISSN 1980-7791

CASTRO JR., Torquato. A Bola do Jogo: uma metáfora performativa para o desafio da pragmática da norma jurídica. In: Adeodato, J. M.; Bittar, E. C. B. (Org.). Filosofia e Teoria Geral do Direito: homenagem a Tercio Sampaio Ferraz Júnior. São Paulo: Quartier Latin, 2011.

PARINI, Pedro. A análise retórica na teoria do direito. Cadernos do Programa de Pós-Graduação em Direito/UFRGS. Vol. 12, nº 1, 2017.

A retórica da metáfora dos modelos na teoria do direito. Seqüência (Florianópolis), n. 67, dez. 2013, p. 81-110.

Retórica como método no direito: o entimema e o paradigma como bases de uma retórica judicial analítica. João Pessoa: Editora da UFPB, 2015.

PERELMAN, Chaïm; OLBRECHTS-TYTECA, Lucie. Tratado da Argumentação: a Nova Retórica. São Paulo: Martins Fontes, 2005.

RODRIGUEZ, José Rodrigo. Como decidem as cortes: para uma crítica do direito (brasileiro). São Paulo: FGV editora, 2013.

SCHROTH, Ulrich; SCHNEIDER, Jochen. Perspectivas da aplicação da norma jurídica: determinação, argumentação e decisão. In: KAUFMANN; HASSEMER (org.) Introdução à filosofia do direito e teoria do direito contemporâneas. Lisboa: Fundação Calouste Gulbenkian, 2002.

SOBOTA, Katharina. Don't mention the norm. International Journal for the semiotics of law IV/10. 1991a, p. 45-60.

The rhetorical construction of law. International Journal for semiotics of law, V/13, 1992, p. 39-54.

. System and flexibility in law. Argumentation. August 1991b, Volume 5, Issue3, p. 275-282.

RECEBIDO EM: 22/09/2018

APROVADO EM: 22/02/2019 